plum stones, and three cherry stones. The button was conted with frees and the tube was blocked by a cherry stone. On the 11th the patient was quite convalescent. He was allowed to get up and take fish and chicken.

Remarks. - The above case is in itself a very interesting one, but its importance principally consists as a record of the successful use of Murpby's button. The great objection to all intestinal resection is the length of time spent in securely suturing the ends of the gut. I was surprised at the facility with which the operation was performed. I was only familiar with the use of the button from the description I had read; and yet I found the reunion of the gut a very easy process. The adaptation of the serous surfaces was so perfect that it was with entire confidence that I returned the bowel into the abdominal cavity. Another point worthy of notice is this : the disparity in the circumference of the bowel above and below the stricture was so great that by the ordinary method of suture very considerable difficulty would have been experienced; but with the button all trouble of this kind was removed.

The Crescent, Plymouth.

\section{YAWS IN BORNEO, NOT CONNECTED WITH SYPHILIS.}

BY SURGEON-CAPTAIN F. SMITH, A.M.S.

HAVING recently met with cases of frambosia in North Borneo which are not mentioned by some of the latest writers on the geographical distribution of the disease, it appeared to me desirable to report them, especially as they seem to throw some light on the question of the relation of yaws to syphilis. While travelling on foot through the jungle I came across a hut belonging to a man of the Dusun tribe. This house stands alone, miles from any other habitation, and the inhabitants have so little intercourse with coast people that they were quite alarmed when told that it was proposed to make a road which would pass their dwelling. The head of the house said, "In that case we must seek a home further away in the woods." The family consisted of father, mother, five children (one at the breast) and a sonin-law. Children Nos. 3 and 4 presented a shocking appearance. At first sight they certainly looked as if they were suffering from severe constitutional syphilis of an uncommon type, but a closer inspection quickly dispelled the idea. My companion, who has lived long in the country and is not a medical man, informed me that the disease was known to him as soft cancer. The best description I can give of the sores is that they were exactly like enormous condylomata, some of them with ulcerating surfaces, others more or less scabbed. A few tubercles had broken down and left ulcers. On one child (eight years of age) the face and neck were affected, and, more sparsely, the arms and legs The other child (five years of age) was covered with tubercles, more particularly about the genitals and buttocks, where some of them were as big as walnuts and presented a mass of such density that the skin was hidden and the valvar opening, the gluteal folds, and cleft between the buttocks could not be made out. The mouth was so surrounded that the child ate with difficulty. This condition of affairs was aggravated by the filthy condition in which the sufferers were kept. The next in age, a boy, was said to have recently had the disease, but was a healthy-looking, robust lad when we saw him. He bore scars around the mouth and on various parts of the body. The eldest daughter and the youngest were healthy, as were the father, mother, and son-in-law. The parents were not much concerned about the sickness; they said it was a common disease and would get well of itself, and the children be as strong as their brother who had got over it. had no opportunity of seeing them again. The Dusuns are familiar with yaws, but syphilis is practically unknown among them. In this instance the father and mother were in good health and there were healthy children older and younger than those affected. Both the father and mother stated that there had been no miscarriages; all the children were alive at the time we visited the place, and they show a regular sequence in point of age (two, five, eight, eleven, and fourteen years). Lactation is prolonged among these people. There were no signs of syphilis to be found in the eyes or teeth of any of the family. The diseased children had no sores inside the mouth or on the hairy scalp, and no evidence of bone affections or periostitis-nothing but the eruption. It is not likely that syphilis would present exactly the same appearances in three children, and in two of them at one time. Syphilis severe enough to have produced such a condition as was present in these cases would have caused serious constitutional disturbance, but the two Dusun children sprang up when we approached; they took a lively interest in us and in some biscuits which we gave them, and they moved about briskly, though their gait was interfered with by their sores. The Dusuns have no idea of the cause of yaws, but they know it to be contagious. These cases do not absolately prove anything, but I think they may beln to elucidate matters. I am sure that no unbiased person who saw this family as I did could doubt that yaws and syphilis are totally distinct diseases. I bave not met with the disease in Malaya-that is, British Malaya-but should imagine that cases will be found in the interior, inasmuch as the disease is said to be prevalent in the neighbouring Dutch possessions, as Java, Sumatra, \&c.

Singapore, Malaya.

\section{Clinital 筑otes:}

MEDICAL, SURGICAL, OBSTETRICAL, AND THERAPEUTICAL.

\section{CURIOUS FOETAL DEFORMITY.}

By L. E. Stevenson, M.B., B.C. Cantab.

ON Oct. 11th of this year I was called to attend a woman, aged twenty-six, multipara. The previous labours, four in number, had been normal. The patient's abdomen was of unusual size, and I found a large bag of membranes protruding through the os during the pains. This I ruptured, and an enormous quantity of liquor amnii flowed away. I could feel the head presenting very high up. There was long delay at the brim, and when the os was sufficiently dilated $r$ applied the forceps, but they slipped off twice. After waiting an hour the head advanced and was then discovered to be hydrocephalic. I at length succeeded in extracting the foetus with the forceps without perforating the head. The foetus was a male and only lived three or four minutes. On further examination later I found the vertebral column so bent and twisted on itself that the anal aperture, though in the median line, was only two inches distant from the base of the skull posteriorly, the pelvis being so tilted that the legs appeared to be growing from the child's back. The umbilical insertion of the cord was greatly dilated, measuring an inch by an inch and a half, there being a corresponding deficiency of the abdominal wall. The anterior parts of the neck were filled in, almost to the level of the chin, by fatty subcutaneous tissue. All the limbs were normal, with the exception of the right leg, the foot of which showed well-marked congenital talipes rarus.

Temple Sowerby, Penrith.

\section{CASE OF CONGENITAL HYDRONEPHROSIS TREATED} SUCCESSFULLY BY A NOVEL METHOD.

By W. Arbuthnot Lane, M.S. Lond., F. R. C.S. Eng., ASSISTANT SURGEON TO GUY'S HOSPITAT AND TO THE HOSPITAL YOF SICK CHILDREN, GREAT ORMOND-STREET.

A Box fourteen years old, small for his age, being about $4 \mathrm{ft} .6$ in. in height, was first attacked by hydronephrosis on the left side in 1885. There was considerable distension of the abdomen, the tumour subsiding spontaneously at the end of four or five weeks. After this he had four or five attacks, each lasting about three or four weeks and then disappearing suddenly. In September, 1893, as he was very much distended, he was tapped by Dr. Freeman of Kimpton, and eighty.four ounces of fluid were drawn off. This quantity did not represent the whole of the fluid contents of the tumour. The abdomen being again enormously distended, on October 11th, 1893, be was tapped by $\mathrm{Mr}$. Bernard Scott of Bournemouth, who drew off two gallons of fluid. Before be was tapped his abdomen measured 
thirty-eight inches in circumference, the apex of the heart beating in the second space, and the distension caused him the greatest distress. A drainage-tube was left in, through which a considerable quantity of urine drained daily into a vessel arranged for the purpose. The abundant discharge of arine through the fistulous opening was the factor that determined the parents in desiring the removal of the tumour, and the operation was therefore performed on Feb. $27 \mathrm{tb}$, 1897. On exposing the outer aspect of the tumour by means of an incision in the left side, and on laying it open, the band entered a cavity of such considerable size that it was felt to be undesirable to incur what wou'd have been a very considerable risk by its removal, especially as the wound might possibly not be asseptic. I therefore examined the exposed portion of the tumour to discover how far the mass was made up of distended pelvis and ureter, and how much of dilated kidney substance. This I arrived at by stripping off the capsule from what was obviously reval tissue, when it was fonnd that about a tenth only of the wall of the cyst was formed of kidney substance, the remainder being apparently made up of the pelvis and ureter enormously dilated. The sidney was carefully cut away along its limits, which were readily indicated by the reflection of its capsule, each portion being firmly ligatured previonsly to being cut through. The ligatures were left long so as to serve as a drain from the cemainder of the cyst-wall left. At no time after the operation did any discharge of urine take place from the wound, which was kept open only by the ligatures, which came away after varying intervals of time.

St. Thomas's-street, S.E.

\section{AN ANTISEPTIC ALKALINE TABLOID FOR NASO-PHARYNGEAL DISEASES.}

By Herbert Tillex, M.D., B.S.LosD., \&c., ASISTAYT SURGEON TO THE LONDON EAR AND THROAT HOSPITAL.

HAVING had more than twelve months' experience with the fabloid about to be described, I can confidently recommend it to the profession for use in those cases of naso-pharyngeal diseases where an alkaline antiseptic wash is advisablesuch cases, for exsmple, as ozæna, chronic nasal catarrh, and purulent discharges from the accessory nasal cavities after removal of polypi, \&c. The obvious difficulty was to combine the carbolic acid and sodium bicarbonate; but after much trouble Messrs. Burroughs and Wellcome succeeded in doing so, and the convenience of the tabloid to patients suffering from diseases similar to those described is inestimable. There is nothing new in the combination of drugs employed, as is seen at once in its composition-viz., twelve graius of bicarbonate of sodium, a grain and a halt of carbolic acid, and two grains of chloride of sodium. I purposely excluded borax, because I shared the experience of some other rhinologists that many patients complain of a sense of dryness in their nose when using lotions containing borax, which disappeared when the latter drug was eliminated from the lotion. The second and most obrious adrantage is that of expense to the patient. Many have to continue using lotions for a long while, and the necessity of having a fresh supply every fifth or sixth day often results in patients giving up a treatment which would much benefit them if continued. The tabloids are very soluble in water, and, indeed, are so hygroscopic that they should be kept well corked. One tabloid dissolved in about two ou aces of lukewarm water gives a solution of sufficient strength for ordinary cases, but the suitable strength can soon be best gauged by the patient himself. A bottle containing 100 tabloids is sold for about $2 s$. and in an ordinary way wonld last about two months. Such a combination of drugs is so commonly ordered in naso-pharyngeal cases that its conFenience in this form is my reason for bringing it to notice.

College-crescent, South Hamivstead, N.W.

BLACKPOOL HosPITAL.-The trustees of this hospital have received through Dr. Kingsbury, the consulting physician, the following donations :-Anonymous (to build two additional wards), $\$ 1000 ; \mathrm{Mr}$. James Parrott (to endow one bed in rerpetuity), $£ 1000$; Miss Haworth, $£ 250$; Mr. James Higgin, £100.

\section{Athirrox}

\section{H O S P I T A L P R A C T I C E, BRITISH AND FOREIGN.}

Nulla autem est alia pro certo noscendi via, nisi quamplurimas et mor borum et dissectionum historias, tum aliorum tum proprias collectas habere, et inter se comparare.-MORGAGNI De Sed. et Caus. Morb. lib. iv. Procmium.

\section{ST. THOMAS'S HOSPITAL.}

A SERTES OF CASES ILLUSTRATING THE SUCCESS ATTENDING THE MODERN METHOD OF OPERATION FOR STRANGULATHD HERNIA.

(Concluded from p. S53.)

(Cases under the care of Mr. W. H. BAtTLE.)

THESE four cases of operation for strangulated hernia are a continuation of the series of which we published seven in the last issue of The LANCET. We consider that they form a very good illustration of the success of the modern method of herniotomy, as they are not selected cases, but represent all hernix which required operation during a period of ten days at one hospital. There is nothing unusual in the methods employed; probably the same cases would have been treated with equal success at any of our large hospitals. None of them presented the more serious conditions which militate against successful operation; there were no cases of gangrene, or ulceration of gut, or of adbesion of intestine to the sac. In all, with one exception, the condition permitted of the performance of a radical cure after reduction of the hernia. In order that a patient may have the best chance afforded by the modern operation, it is necessary that operation should be performed early and that attempts at taxis have not been too severe or too prolonged. This fact is emphasised by the recently published paper by Mr. John Croft, the majority of whose cases were drawn from the district trom which these came. Of forty-four operations for strangulated hernia performed by him with antiseptic precautions nine died exhausted as a result of their protracted sufferings, while five were already moriband when admitted. We hope the series now published may be taken as an indication that recognition of the importance of early operative relief on the failure of moderate taxis is better appreciated thar it was amongst those who see the patients first. At all events, we would impress on the profession the fact that the mortality from strangulated hernia has no right to be so high as 35.8 per cent., as was recently estimated to be the average at a large hospital. When our students are fully impressed with the importance and aafety of early operation it will not be long before the public recognises it. So many operations have been performed in the past on patients who have died soon afterwards that there is still trouble to make friends understand that it is not the operation that kills but its performance on an exhausted patient. The immensely important points in these cases are evident on reading the account. We would, however, draw attention to the rarity of interstitial hernia (forming 0.13 per cent. of all cases of inguinal hernia in the male), of which Case 8 is a good example of the more usual of the three varieties into which they are divided; and to the effect of tazis in Case 9 , the local effect of ice on the contents of the sac. and to the temporary albuminuria of unexplained origin. In Case 10 the patient was a stout man, who complained of no cough or illness before admission, but was probably alcoholic. How far the ether may have acted in arousing a latent tuberculous focus it is not possible to say. Without actual examination of the sac and its contents it was hardly possible to tell for certain that the hernia was a direct one. The great similarity of the two hernix, their shape, and the fact that they did not enter the scrotum, together with their short duration, made it probable. The gut was evidently sharply nipped in Case 11, for the patient suffered much more pain than usual, and after the relief of strangulation there was a complaint of abdominal pain ard discomfort, only relieved by the passage of the long tube and 